\title{
NIETZSCHE: DA GENEALOGIA À TRANSVALORAÇÃO DOS VALORES ${ }^{1}$
}

\author{
[NIETZSCHE: FROM GENEALOGY TO THE OVERVALUATION OF VALUES]
}

\author{
Scarlett Marton * \\ Universidade de São Paulo, Brasil
}

\begin{abstract}
Resumo: O presente trabalho tem por objetivo esclarecer de que forma a noção de valor assume um papel fundamental para compreensão da última fase da obra de Nietzsche. Para levar essa tarefa a cabo, realizaremos um exame de dois temas centrais no pensamento nietzschiano, a saber, o procedimento genealógico e o projeto de transvaloração dos valores. Assim procedendo, o artigo percorrerá boa parte das principais questões da filosofia nietzschiana, tais como: $o$ caráter humano demasiado humano dos valores; a dupla forma de valorar e criar valores; o ressentimento; a morte de Deus; o niilismo e o além-do-homem. A intenção é destacar que a noção de valor - inseparável tanto do aspecto crítico e corrosivo do pensamento de Nietzsche, quanto de sua faceta propositiva - permeia e dá sentido aos temas acima elencados.
\end{abstract}

Palavras-chaves: valor; procedimento genealógico; transvaloração dos valores
ABSTRACT: This work aims to clarify how the notion of value assumes a fundamental role in understanding the last phase of Nietzsche's work. In order to accomplish this task, we will carry out an examination of two central themes in the Nietzschean thought, namely, the genealogical procedure and the project of transvaluing values. In doing so, the article will cover a good part of the main issues of Nietzschean philosophy, such as: the all too human character of values; the dual way of valuing and creating values; the resentment; the death of God; nihilism and the beyond-man. The intention is to highlight that the notion of value - inseparable from both the critical and corrosive aspect of Nietzsche's thought, as well as from its creative side - permeates and gives meaning to the themes listed aabove.

KEYWORDS: value; genealogy; revaluation of values

Central na obra de Nietzsche, a noção de valor desempenha papel de primeira
importância tanto no procedimento genealógico quanto no projeto de transvaloração de todos os valores. Importa notar, porém, que essa noção só se torna operatória a partir de Assim falava Zaratustra. Antes, Aurora apresentava o subtítulo "pensamentos sobre preconceitos morais", O Andarilho e sua Sombra tratava de sentimentos morais, Humano, demasiado Humano examinava conceitos morais. Nietzsche tratava de conceitos, pré-juízos, sentimentos em suas considerações sobre a moral e, eventualmente até chegava a empregar o termo "valor" ou a expressão "apreciações de valor". ${ }^{2}$ Mas a partir de seu livro mais dileto passa a trabalhar com a noção de valor. Isso possibilita uma reorganização de seu pensamento: suas ideias são

* Professora titular da Universidade de São Paulo, autora de Nietzsche e a arte de decifrar enigmas. Treze conferências europeias. São Paulo: Loyola, 2014, entre vários outros. E-mail: smarton@usp.br 
submetidas à nova articulação; seus escritos são por ele mesmo encarados segundo nova ótica, como deixam entrever os prefácios de 1886 aos livros já publicados e a chamada autobiografia intitulada Ecce Homo de 1888.

A Assim falava Zaratustra, seguem Para além de Bem e Mal e Genealogia da Moral $^{3}$. Examinados de perto, esses três livros revelam uma certa continuidade. Dentre os vários elementos que viriam assegurá-la, não podemos deixar de sublinhar o procedimento genealógico. Não há dúvida de que o termo "genealogia" aparece apenas na Genealogia da Moral; tampouco há dúvida de que é nessa obra que se precisa a tarefa genealógica. ${ }^{4}$ Tanto é que, logo no prefácio, Nietzsche escreve:

Precisamos de uma crítica dos valores morais, devemos começar por colocar em questão o valor mesmo desses valores; isto supõe o conhecimento das condições e circunstâncias de seu nascimento, de seu desenvolvimento, de sua modificação (a moral como consequência, sintoma, máscara, tartufaria, doença, malentendido, mas também como causa, remédio, stimulans, empecilho ou veneno), enfim, um conhecimento tal como nunca existiu até o presente e como nem mesmo se desejou. ${ }^{5}$

Então, o filósofo deixa claro que não se deve confundir genealogia e gênese. ${ }^{6}$ Enquanto o procedimento genético se volta para a busca da origem das coisas, pressupondo com isso que elas teriam uma essência, o genealógico vem precisamente fazer a crítica da noção de essência, levantando a pergunta pelo valor que às coisas se atribui ao longo do tempo.

Ao trabalhar com a noção de valor na Genealogia da Moral, Nietzsche opera uma subversão crítica. Com essa noção, ele põe de imediato a questão do valor dos valores e, ao colocá-la, levanta a pergunta pela criação dos valores. Se o valor dos valores "bem" e "mal" não chegou a ser posto em questão, é porque eles foram vistos como se existissem desde sempre: instituídos num além, encontravam legitimidade num mundo suprassensível. No entanto, uma vez questionados, revelam-se apenas "humanos, demasiado humanos"; em algum momento e em algum lugar, simplesmente foram criados. ${ }^{7}$ Assim o valor dos valores está em relação com a perspectiva a partir da qual ganharam existência. Não basta, contudo, relacioná-los com os pontos de vista de apreciação que os engendraram; é preciso ainda investigar de que valor estes partiram para criá-los. $\mathrm{Na}$ ótica nietzschiana, a questão do valor apresenta duplo caráter: os valores supõem avaliações, que lhes dão origem e conferem valor; estas, por sua vez, ao criá-los, supõem valores a partir dos quais avaliam. ${ }^{8}$

Uma passagem da Genealogia da Moral pode servir para ilustrar, pelo menos em parte, essa questão.

O levante dos escravos na moral começa quando o ressentimento mesmo se torna criador e pare valores: o ressentimento de seres tais, aos quais está vedada a reação propriamente dita, o ato, e que somente por uma vingança imaginária ficam quites. Enquanto toda moral nobre brota de um triunfante dizer-sim a si próprio, a moral de escravos diz não, logo de início, a um 'fora', a um 'outro', a um 'não-mesmo': e esse 'não' é seu ato criador. Essa inversão do olhar que põe valores - essa direção necessária para fora, em vez de voltar-se para si próprio pertence, justamente, ao ressentimento: a moral de escravos precisa sempre, para surgir, de um mundo oposto e exterior, precisa, dito fisiologicamente, de estímulos externos para em geral agir - sua ação é, desde o fundamento, por reação. ${ }^{9}$

Torna-se possível, portanto, traçar uma dupla história dos valores "bem" e - 
"mal". ${ }^{10} \mathrm{O}$ fraco concebe primeiro a ideia de "mau", com que designa os nobres, os corajosos, os mais fortes do que ele - e então, a partir dessa ideia, chega como antítese à concepção de "bom", que se atribui a si mesmo. O forte, por sua vez, concebe espontaneamente o princípio "bom" a partir de si mesmo e só depois cria a ideia de "ruim" como "uma pálida imagem-contraste". Para o forte, "ruim" é apenas uma criação secundária; para o fraco, "mau" é a criação primeira, o ato fundador da sua moral.

A partir daí, chegamos a algumas conclusões. Em primeiro lugar, o valor "bom" da moral dos nobres deve ser diferente do valor "bom" da moral dos escravos. Enquanto os valores "bom" e "ruim" foram criados por um ponto de vista nobre de apreciação, "bom" e "mau" foram engendrados a partir da perspectiva avaliadora dos escravos. Ao valor "bom" da moral dos nobres não se atribui, pois, o mesmo valor que ao "bom" da moral dos escravos. Uma vez que o primeiro surge de um movimento de autoafirmação e o último, de negação e oposição, eles não podem ser equivalentes. ${ }^{11}$ Em segundo lugar, o valor "bom" de uma moral corresponde exatamente ao valor "mau" da outra. Enquanto os fortes afirmam: "nós nobres, nós bons, nós belos, nós felizes", os fracos dizem: "se eles são maus, então nós somos bons". Portanto, "mau" no sentido da moral do ressentimento é precisamente o nobre, o corajoso, o mais forte, é o "bom" da moral dos senhores. Em terceiro lugar, a moral dos escravos surge de uma inversão dos valores; seu ato inaugural não passa de reação. Na medida em que o valor "mau" da moral do ressentimento corresponde ao valor "bom" da outra moral, os ressentidos não criam propriamente valores; limitam-se a inverter os que foram postos pelos nobres.

Não basta, contudo, mostrar que os valores foram engendrados a partir de lógicas diferentes, foram postos por pontos de vista de apreciação distintos. Não basta relacioná-los com as perspectivas avaliadoras que os engendraram; é preciso ainda investigar de que valor estas partiram para criá-los. Na ótica nietzschiana, a questão do valor apresenta duplo caráter: os valores supõem avaliações, que lhes dão origem e conferem valor; estas, por sua vez, ao criá-los, supõem valores a partir dos quais avaliam. O procedimento genealógico comporta, assim, dois movimentos inseparáveis: de um lado, relacionar os valores com avaliações, de outro, relacionar as avaliações com valores. Remete-se os valores às avaliações que os engendraram, quando se afirma que "bom" e "ruim" foram criados por um ponto de vista nobre de apreciação, enquanto "bom" e "mau" surgiram da perspectiva avaliadora dos escravos. Mas isso não é tudo: é preciso ainda remeter a moral dos nobres e a moral dos escravos a valores, avaliar essas duas avaliações. Não se trata, porém, de relacioná-las com os valores "bem" e "mal", porque foram engendrados por elas; não se trata de questionar se a moral dos nobres é melhor - ou pior - que a moral dos escravos, porque implicaria incorrer num círculo vicioso. Trata-se - isto sim - de adotar um critério de avaliação que não possa ser avaliado. Podemos afirmar sem medo de errar que, no entender de Nietzsche, o único critério que se impõe por si mesmo é a vida. Assim é que no Crepúsculo dos Ídolos ele escreve:

É preciso estender os dedos, completamente, nessa direção e fazer o ensaio de captar essa assombrosa finesse - de que o valor da vida não pode ser avaliado. Por um vivente não, porque este é parte interessada, e até mesmo objeto de litígio, e não juiz; por um morto não, por uma outra razão. ${ }^{12}$

Fazer qualquer apreciação passar pelo crivo da vida equivale a perguntar se 
contribui para favorecê-la ou obstruí-la; submeter ideias ou atitudes ao exame genealógico é o mesmo que inquirir se são signos de plenitude de vida ou de sua degeneração; avaliar uma avaliação, enfim, significa questionar se é sintoma de vida ascendente ou declinante.

Ao considerarmos a Genealogia da Moral enquanto um todo, desde logo notamos que o movimento do texto é tal, que começa com a recusa de encontrar na metafísica o fundamento último dos valores morais e termina com a denúncia dos postulados metafísicos insidiosamente presentes na moral dos escravos. Inventando outro mundo, os ressentidos reinstauram princípios transcendentes, tomando-os por base da moralidade; com isso, desprezam o mundo em que se encontram e negligenciam o caráter "humano, demasiado humano" dos valores que eles mesmos instituíram. Depois de explicitar a perspectiva que pretende adotar para refletir sobre as questões morais, Nietzsche examina, num primeiro momento, os valores "bem" e "mal" tal como foram engendrados pela maneira nobre e pela maneira escrava de avaliar. Analisa, em seguida, o modo de proceder do homem do ressentimento, mostrando como surgiram a "culpa", a "justiça", o "castigo" e a "má consciência". Investiga, por fim, o trabalho dos ressentidos na arte, na filosofia, na religião e na ciência, deixando claro que elas são inspiradas pelo ideal ascético. Mas, nas três Dissertações, faz passar pelo crivo da genealogia a moral, o comportamento e até a produção do homem do ressentimento, submetendo-os também a uma avaliação - e julgando-os enfermidades. Em todos os níveis, trata-se de tentativas, por parte dos que não têm força para lutar, de escamotear a luta e denegrir a vida, que, no entender do filósofo, nada mais é do que luta sem trégua ou termo. A Genealogia da Moral apresenta-se, pois, como o texto, em que o autor não só explicita o procedimento genealógico como ainda opera claramente com ele.

Importa notar que, no contexto do pensamento nietzschiano, os conceitos de vida e valor se acham intimamente ligados. Em Para além de Bem e Mal, o filósofo define:

Viver é essencialmente apropriação, violação, dominação do que é estrangeiro e mais fraco, opressão, dureza, imposição da própria forma, incorporação e pelo menos, no mais clemente dos casos, exploração. ${ }^{13}$

A partir daí, estamos em condições de compreender que ele encare a moral cristã como negação da vida e afirme que a vida, do ponto de vista moral, está errada. ${ }^{14}$ Compreendemos também que ataque o altruísmo, a renúncia de si, o amor ao próximo e todas as chamadas virtudes cristãs, por um lado, e considere a crueldade, o egoísmo, o ódio, a inveja, a cupidez como impulsos vitais, por outro. ${ }^{15}$ Compreendemos, enfim, que, se tivesse sentido falar em bem e mal, consideraria bom "tudo o que satisfaz no homem o sentimento de potência, a vontade de potência, a própria potência", e mau, "tudo o que provém da fraqueza."16 Moral, política, religião, ciência, arte, filosofia, qualquer apreciação de qualquer ordem deve ser submetida a um exame, deve passar pelo crivo da vida.

A estreita ligação entre os conceitos de vida e valor já aparece em Assim falava Zaratustra. Então, o protagonista diz a seus interlocutores: "mas para entenderdes minha palavra de bem e mal: para isso quero dizer-vos ainda minha palavra da vida, e do modo de todo vivente." ${ }^{17}$ É também nesse livro que Nietzsche deixa entrever o seu projeto de transvaloração de todos os valores.

Assim falava Zaratustra abre-se com o anúncio da transformação pela qual o protagonista acaba de passar. Durante uma década, ele permaneceu na solidão de sua 
caverna e de sua montanha; "por fim, seu coração transformou-se"18. Dirigindo-se ao vale, onde irá ter com os homens, encontra seu primeiro interlocutor. Surpreso, o santo homem do bosque exclama: "Não me é estranho este andarilho"19; há muitos anos passou por aqui. Chamava-se Zaratustra; mas transformou-se." ${ }^{20}$ Ao avistá-lo, percebe de imediato que mudanças ocorreram. E prossegue:

Outrora levavas tua cinza para o monte ${ }^{21}$; queres hoje levar teu fogo para o vale $^{22}$ ? Não temes os castigos contra os incendiários? Sim, reconheço Zaratustra. Puro é seu olhar e não há nojo em sua boca. Não caminha por isso como um dançarino ${ }^{23}$ ? Transformado está Zaratustra, uma criança tornou-se Zaratustra, um desperto $^{24}$ é Zaratustra; o que queres agora entre os que dormem ${ }^{25}$

Ao vê-lo, logo compreende a relevância das mudanças que ocorreram.

Desde as primeiras páginas do prólogo, Zaratustra aparece como o anunciador de uma completa reviravolta em nossa cultura. E, aos poucos, a transformação por que acaba de passar ganha clareza. Sua causa então se explicita: ela reside no conhecimento da morte de Deus ${ }^{26}$. Se foi no mundo supra-sensível que até então os valores encontraram legitimidade, trata-se agora de suprimir o solo mesmo a partir do qual eles foram colocados, para então engendrar novos valores. "Humanos, demasiado humanos", os valores instituídos surgiram em algum momento e em algum lugar ${ }^{27}$. E, em qualquer momento e em qualquer lugar, novos valores poderão vir a ser criados. É a morte de Deus, pois, que permitirá a Nietzsche acalentar o projeto de transvalorar todos os valores.

Traço essencial de nossa cultura, o dualismo de mundos foi invenção do pensar metafísico e fabulação da religião cristã. Com Sócrates, teve início a ruptura da unidade entre physis e logos - e a filosofia converteu-se, antes de mais nada, em antropologia. Com o judaísmo, houve o despovoamento de um mundo que estava cheio de deuses - e a religião tornou-se, acima de tudo, um "monotono-teísmo"28. Desvalorizando este mundo em nome de um outro, essencial, imutável e eterno, a cultura socrático-judaicocristã é niilista desde a base. É a morte de Deus, pois, que tornará possível a Zaratustra fazer a travessia do niilismo.

Aos homens Zaratustra espera levar um duplo presente. Aos homens ele conta dar um novo amor e um novo desprezo: o além-do-homem e o último homem ${ }^{29}$. Diametralmente opostas são as perspectivas para as quais eles apontam. Abraçar a primeira delas implica aceitar a morte de Deus e a conseqüente morte do homem enquanto criatura em relação a um Criador $^{30}$; esposar a última importa advogar a existência de um mundo transcendente e, por conseguinte, reiterar a interpretação cristã do mundo. Enquanto a perspectiva aberta pelo além-do-homem viabiliza criar novos valores, a estabelecida pelo último homem exige a defesa dos valores instituídos.

Até agora foi o homem, concebido enquanto criatura em relação a um Criador, quem avaliou; e os valores que criou desvalorizaram a Terra, depreciaram a vida, desprezaram o corpo. É preciso, pois, combatê-los, para que surjam outros ${ }^{31}$. É preciso denunciar que se forjou a alma "para arruinar o corpo", que se inventou o "mundo verdadeiro" enquanto "nosso atentado mais perigoso contra a vida", que se fabulou a noção de Deus como "a máxima objeção contra a existência". ${ }^{32}$ Só então será possível engendrar uma nova concepção de humanidade; só então será possível criar novos valores. Tornando-se criatura e criador de si mesmo, o além-do-homem prezará os valores em consonância com a Terra, com a vida e com o corpo. ${ }^{33}$

Transvalorar é, antes de mais nada, suprimir o solo a partir do qual os valores até 
então foram engendrados. Aqui, Nietzsche espera realizar obra análoga à dos iconoclastas: derrubar ídolos, demolir alicerces, dinamitar fundamentos. É deste ponto de vista que critica a metafísica, a religião e a moral.

Em Assim falava Zaratustra, aqueles a quem a personagem se opõe já aparecem nas primeiras linhas - o cristianismo e o platonismo. Depois de abrasar a terra, o sol tem de pôr-se no horizonte; depois de saturar-se de sabedoria, Zaratustra tem de voltar ao convívio com os homens. Aos quarenta anos, ele tem de descer da montanha para o vale, dos cumes para as profundezas, do mundo para o submundo; por excesso, ele tem de declinar ${ }^{34}$. À diferença dos Evangelhos ${ }^{35}$, porém, é aos quarenta e não aos trinta anos que começa seu ministério e, ao contrário da República ${ }^{36}$, é na caverna e não fora dela que se faz sábio. O deslocamento espaço-temporal não é gratuito; indica distância e recuo em relação a referenciais milenares de nossa cultura. Não é por constatar a miséria do ser humano, querer resgatá-lo e salvá-lo que Zaratustra vai ter com os homens - mas por estar farto da própria sabedoria. Não é por perfazer a ascese dialética, abandonando a diversidade sensível e contemplando a verdade inteligível, que ele desce da montanha para o vale - mas por compreender que tal dicotomia não existe. O que o move não é a penúria alheia mas a própria abundância; o que o impulsiona não são as carências do homem mas o transbordamento do mundo. Presente já na primeira página, ainda que de forma alusiva, a crítica ao dualismo metafísico e à religião cristã, aliada aos ataques à moral do ressentimento que deles decorre, será uma constante no livro.

Transvalorar é, também, inverter os valores. Aqui, Nietzsche conta realizar obra análoga à dos alquimistas: transformar em "ouro"37 o que até então foi odiado, temido e desprezado pela humanidade. É deste ângulo de visão que denuncia o idealismo e reivindica a efetividade ${ }^{38}$.

Em Assim falava Zaratustra, logo depois de anunciar a morte de Deus, a personagem dirige-se à multidão reunida na praça do mercado. É então que exorta seus ouvintes a permanecerem fiéis à Terra. Se outrora o maior delito era o cometido contra Deus, agora mais sacrílego ainda é delinqüir contra a Terra. Se outrora a alma mostrava descaso pelo corpo, agora é o corpo que torna evidente a miséria da alma. Se outrora o homem, enquanto criatura em relação a um Criador, dava sentido ao que o cercava, agora ele não passa de ponte para o além-do-homem ${ }^{39}$. É chegada “a hora do grande desprezo"40; é chegado o momento de desdenhar tudo o que até então se venerou e, pelo mesmo movimento, afirmar tudo o que até então se negou. Só assim será possível revelar o que por trás dos valores instituídos se esconde e trazer à luz o que eles mesmos escondem. Não é por acaso que o termo transvaloração (Umwertung) também abriga a ideia de inversão (Umkehrung). Eliminando as esperanças ultraterrenas, Zaratustra, "o sem-Deus", conta naturalizar os valores morais. Suprimindo o além, Nietzsche, "o anticristo", quer reinscrever o homem na natureza, estabelecer nova aliança entre physis e $\log \operatorname{os}^{41}$.

Transvalorar é, ainda, criar novos valores. Aqui, Nietzsche pretende realizar obra análoga à dos legisladores: estabelecer novas tábuas de valores. É desta perspectiva que concebe a filosofia.

Em Assim falava Zaratustra, ao eleger os seus interlocutores, a personagem determina-se a falar para companheiros de viagem. Junto com eles espera "escrever novos valores em novas tábuas"42. Pouco importa que a eles se chame de "aniquiladores e desprezadores do bem e do mal"; pouco importa que sejam considerados delinqüentes. Afinal, todo criador é um infrator. Em Para além de bem e mal, ao 
escolher os seus pares, o autor identifica "os filósofos propriamente ditos" a "comandantes e legisladores" presente momento; salienta que é necessário que existam. Eles podem, por certo, contar com os esforços despendidos por "todos os trabalhadores filosóficos" em detectar, analisar, fundamentar e mesmo questionar os valores instituídos. Mais ainda, podem e talvez até devam passar por um processo preparatório, assumindo na apreciação desses valores os mais diversos pontos de vista, inclusive o dos "trabalhadores filosóficos". Mas o seu trabalho começa onde o destes se detém; tanto é que eles inovam, enquanto os outros compactuam.

A travessia do niilismo, a noção de além-do-homem e o projeto de transvaloração dos valores estão presentes em Assim falava Zaratustra; acham-se intimamente ligados desde as primeiras páginas do livro. É de forma exemplar que aparecem no discurso intitulado "Dos mil e Um alvos". Assim ensina Zaratustra:

Em verdade, os homens se deram todo o seu bem e mal. Em verdade, eles não o tomaram, eles não o encontraram, não lhes caiu como uma voz do céu. Valores foi somente o homem que pôs nas coisas ${ }^{44}$, para se conservar - foi ele somente que criou sentido para as coisas, um sentido de homem! Por isso ele se chama de 'homem', isto é: o estimador ${ }^{45}$. Estimar é criar: ouvi isto, ó criadores! ${ }^{46}$

Ao fazer ver que os valores são "humanos, demasiado humanos", ao atribuirlhes uma proveniência e uma história, a personagem desmantela o solo mesmo a partir do qual até então foram colocados. Com o combate ao dualismo de mundos, põe por terra a interpretação imposta pelo pensar metafísico e pela religião cristã. Atento ao vazio que se instala, quando tal interpretação desmorona, desqualifica a ideia de que nada vale a pena, de que tudo é em vão. Com isso, perfaz a travessia do niilismo ${ }^{48}$. À existência humana o autor quer dar um novo sentido. E, para tanto, sabe que é preciso conceber o homem de outra maneira. Entendendo-o enquanto parte integrante deste mundo, é em além-do-homem que o converte; só então será possível transvalorar todos os valores. Mas também sabe que destruir e construir são as duas faces da mesma moeda. Tanto é que são estas as palavras que ele põe na boca da personagem: "Ouvi isto, ó criadores! Mutação dos valores - essa é a mutação daqueles que criam. Sempre aniquila, quem quer ser um criador" 49

Assim se revela o lugar que a noção de valor ocupa no pensamento nietzschiano. Ela é central tanto na crítica corrosiva dos valores quanto na construção de uma nova visão de mundo.

\section{REFERÊNCIAS}

Obras de Nietzsche:

NIETZSCHE. Werke. Kritische Studienausgabe (KSA). Berlim: Walter de Gruyter \& Co., 15 vols., $1967 / 1978$.

NIETZSCHE. Sämtliche Briefe. Kritische Studienausgabe (KSAB). Berlim: Walter de Gruyter \& Co., 8 vols., 1975/1984.

NIETZSCHE. Obras Incompletas. Trad. Rubens Rodrigues Torres Filho. São Paulo: Abril

Outras obras: Cultural, $2^{a}$ ed., 1978 (Coleção “Os Pensadores").

ANDLER, Charles. Nietzsche, sa vie et sa pensée. Paris: Gallimard, 1958, tomo II.

BÍBLIA SAGRADA. Trad. João Ferreira de Almeida. Rio de Janeiro: Sociedade Bíblica do Brasil, 1968. 
CONWAY, Dan. Nietzsche's On the Genealogy of Morals: A Reader's Guide. Londres: Continuum, 2007.

DELEUZE, Gilles. Nietzsche et la philosophie. Paris: PUF, $4^{\text {a }}$ ed., 1973.

FOUCAULT, Michel. Les mots et les choses. Paris: Gallimard, 1966.

FOUCAULT, Michel. "Nietzsche, la généalogie, l'histoire". In: BACHELARD, Suzanne et allii. Hommage à Jean Hyppolite. Paris: PUF, 1971.

HATAB, Lawrence. Nietzsche's On the Genealogy of Morality - An Introduction. Cambridge: Cambridge University Press, 2008.

HEIDEGGER, Martin. "Nietzsche's Wort 'Gott ist tot'”. In: Holzwege. Frankfunt am Main: Vittorio Klostermann, 2a ed., 1952.

JANAWAY, Christopher. Beyond Selflessness. Reading Nietzsche's Genealogy. Oxford: Oxford University Press, 2007.

LÖWITH, Karl. Nietzsches Philosophie der ewigen Wiederkehr des Gleichen. Hamburgo: Felix Meiner Verlag, $3^{\text {a }}$ ed., 1978.

LÖWITH, Karl. "Nietzsche et sa tentative de récupération du monde". In: Nietzsche, Cahiers de Royaumont. Paris: Minuit, 1967.

MARTON, Scarlett. "Foucault leitor de Nietzsche". In: MARTON, Scarlett. Extravagâncias. Ensaios sobre a filosofia de Nietzsche. Discurso Editorial/Barcarolla, 3ª ed., 2009, p. 199211.

MARTON, Scarlett. "A morte de Deus e a transvaloração dos valores", in Extravagâncias. Ensaios sobre a filosofia de Nietzsche. São Paulo: Barcarolla, $3^{\mathrm{a}}$ ed., 2009.

OLDENBERG. Buddha, sein Leben, seine Lehre, seine Gemeinde. Berlim: 1881.

OWEN, David. Nietzsche's Genealogy of Morality. Stocksfield: Acumen Publishing Limited, 2007.

PLATÃO. République. Trad. Émile Chambry. Paris: Belles Lettres, 1933, livro VII.

SCHACHT, Richard (org.). Nietzsche, Genealogy, Morality. Berkeley: University of California Press, 1994.

STEGMAIER, Werner. Nietzsches "Genealogie der Moral”. Darmstadt: Wissenschaftliche Buchgesellschaft, 1994.

\section{Notas}

1 Parte deste texto foi publicada numa versão anterior sob o título "A morte de Deus e a transvaloração dos valores", in Extravagâncias. Ensaios sobre a filosofia de Nietzsche. São Paulo: Barcarolla, $3^{\text {a }}$ ed., 2009.

2 Bem se sabe que Nietzsche tomou de empréstimo a noção de valor da economia política. Também se inspirou em Eugen Dühring, em especial no livro $O$ Valor da Vida publicado em 1865. As várias referências que faz a esse pensador, sobretudo as que se acham em Genealogia da Moral, "Segunda Dissertação", § 11, revelam que conhecia as suas obras.

3 A partir de 1990, vários comentadores voltaram-se para esse livro. Cf. por exemplo SCHACHT, Richard (org.). Nietzsche, Genealogy, Morality. Berkeley: University of California Press, 1994; STEGMAIER, Werner. Nietzsches "Genealogie der Moral". Darmstadt: Wissenschaftliche Buchgesellschaft, 1994; JANAWAY, Christopher. Beyond Selflessness. Reading Nietzsche's Genealogy. Oxford: Oxford University Press, 2007; CONWAY, Dan. Nietzsche's On the Genealogy of Morals: A Reader's Guide. Londres: Continuum, 2007; OWEN, David. Nietzsche's Genealogy of Morality. Stocksfield: Acumen Publishing Limited, 2007; HATAB, Lawrence. Nietzsche's On the Genealogy of Morality - An Introduction. Cambridge: Cambridge University Press, 2008.

4 Com o termo "genealogia", Nietzsche vem precisar o que designava em Para além de Bem e Mal pela expressão "história natural da moral". A ideia, aliás, já se acha de certo modo presente em Humano, demasiado Humano, em particular no capítulo intitulado "Contribuição à história dos sentimentos morais".

5 Genealogia da Moral, "Prefácio", § 6, KSA 5.253. Salvo indicação em contrário, é de minha responsabilidade a traduçáo dos textos de Nietzsche aqui citados. 
6 A esse propósito, cf. FOUCAULT, Michel. "Nietzsche, la généalogie, l'histoire". In: BACHELARD, Suzanne et allii. Hommage à Jean Hyppolite. Paris: PUF, 1971, p.146172. Sobre a minha posição acerca de sua interpretação do pensamento nietzschiano, remeto a "Foucault leitor de Nietzsche". In: MARTON, Scarlett. Extravagâncias. Ensaios sobre a filosofia de Nietzsche. Discurso Editorial/Barcarolla, $3^{\text {a }}$ ed., 2009, p. 199-211.

7 Essa preocupação já aparece em Humano, demasiado Humano. Na Genealogia da Moral, Nietzsche refere-se àquele texto e afirma: "meus pensamentos sobre a procedência de nossos preconceitos morais - pois disso se trata neste escrito polêmico -, receberam sua primeira, parcimoniosa e provisória expressão naquela coletânea de aforismos que leva o título Humano, demasiado Humano. Um livro para espíritos livres, e cuja redação foi começada em Sorrento, durante um inverno, que me permitiu fazer alto, como um andarilho faz alto, e abarcar com o olhar o vasto e perigoso país através do qual meu espírito até então fizera sua andança. Isso aconteceu no inverno de 1876/77; os pensamentos mesmos são mais velhos. Eram, no principal, já os mesmos pensamentos que retomo nas presentes dissertações: - esperemos que o longo intervalo lhes tenha feito bem, que eles se tenham tomado mais maduros, mais claros, mais fortes, mais perfeitos!" (Genealogia da Moral, "Prefácio", § 2, traduzido por Rubens Rodrigues Torres Filho, doravante designado como RRTF, KSA 5.248)

8 Sigo aqui a interpretação de Deleuze, que analisou com clareza a noção nietzschiana de valor, assim como o procedimento genealógico. Cf. DELEUZE, Gilles. Nietzsche et la philosophie. Paris: PUF, $4^{\mathrm{a}}$ ed., 1973, em particular, as três primeiras partes do capítulo "O Trágico".

9 Genealogia da Moral, "Primeira Dissertação", § 10 (RRTF), KSA 5.270s.

10 A esse propósito, cf. Humano, demasiado Humano $\S 45$ e $\S 96$, que prenunciam essa ideia, e Para além de Bem e Mal $\$ 260$, que a expõe.

11 Na Genealogia da Moral, "Primeira Dissertação", § 11, KSA 5.274, Nietzsche escreve: "esse 'ruim' (schlecht) de origem aristocrática e esse 'mau' (böse) fermentado na cuba de um ódio insaciável - o primeiro uma criação posterior, um acessório, uma cor complementar; o segundo, ao contrário, o original, o começo, o ato verdadeiro na concepção de uma moral de escravos - 'ruim' e 'mau', quão diferentes são essas duas palavras, aparentemente opostas ao mesmo conceito 'bom'! Mas não é o mesmo conceito 'bom': que se pergunte, antes, quem é 'mau' propriamente dito no sentido da moral do ressentimento. Com todo rigor, cumpre responder é precisamente o 'bom' da outra moral, precisamente o nobre, o poderoso, o senhor, apresentado sob outras cores, reinterpretado e deformado pelo olhar intoxicado do ressentimento."

12 Crepúsculo dos Ídolos, "O problema de Sócrates", § 2 (RRTF), KSA 6.68. Nessa mesma direção, podemos ler em Crepúsculo dos Ídolos, "Moral como contranatureza", § 5 (RRTF), KSA 6.86: "seria preciso ter uma posição fora da vida e, por outro lado, conhecê-la tão bem quanto um, quanto muitos, quanto todos, que a viveram, para poder em geral tocar o problema do valor da vida: razões bastantes para se compreender que este problema é um problema inacessível a nós."

13 Para além de Bem e Mal § 259, KSA 5.207.

14 Cf. Fragmento póstumo 14 [134] da primavera de 1888 e Nascimento da Tragédia, "Ensaio de autocrítica", $\S 5$.

15 Tais ideias aparecem em vários aforismos de Para além de Bem e Mal (por exemplo, no 23) e estão presentes na Genealogia da Moral, em particular nos parágrafos 7 e 11 da Segunda Dissertação.

16 O Anticristo $\S 2$, KSA 6.170.

17 Assim falava Zaratustra II, "Da superação de si” (RRTF), KSA 4.147.

18 Assim falava Zaratustra, "Prólogo", $1^{\mathrm{a}}$ Seção, KSA 4.11.

19 O próprio Zaratustra define-se como andarilho em Assim falava Zaratustra III "O andarilho". 20 Assim falava Zaratustra, "Prólogo", 2" seção, KSA 4.12.

21 A ideia reaparece em Assim falava Zaratustra I, "Dos ultramundanos"; I, "Do caminho do criador"; II, "O adivinho".

22 Como Prometeu, Zaratustra levaria o fogo aos homens. 
23 Em Assim falava Zaratustra IV, "Do homem superior", $18^{\mathrm{a}}$ Seção, Zaratustra também se autodenomina dançarino.

24 Cf. OLDENBERG. Buddha, sein Leben, seine Lehre, seine Gemeinde. Berlim: 1881, p. 113. O adjetivo, aliás, aparece freqüentemente associado a Buda. Nietzsche não só possuía em sua biblioteca o trabalho de Hermann Oldenberg, como, ao que observa Andler, mais de uma vez manifestou sua admiração por ele (cf. ANDLER, Charles. Nietzsche, sa vie et sa pensée. Paris: Gallimard, 1958, tomo II, p. 415).

25 Assim falava Zaratustra, "Prólogo", 2 seção, KSA 4.12.

26 Cf. A Gaia Ciência $\S 125$, onde o tema aparece pela primeira vez na obra do filósofo. Não é por acaso que ele vai retomá-lo no primeiro aforismo do quinto livro de A Gaia Ciência (§ 343), escrito depois da elaboração de Assim falava Zaratustra.

27 Para além de Bem e Mal e a Genealogia da Moral retomam as ideias presentes em Assim falava Zaratustra. No que diz respeito a serem os valores "humanos, demasiado humanos", cf. Genealogia da Moral, "Prefácio", § 6.

28 A expressão é de Nietzsche em O Anticristo $§ 19$.

29 Cf. Fragmento Póstumo 4 [167] de novembro de 1882/ fevereiro de 1883, que apresenta um esboço para esta seção.

30 No entender de Löwith, "A morte de Deus exige do homem que se quer a si mesmo, além do processo da libertação de Deus, uma superação do homem: o 'além-do-homem"” (LÖWITH, Karl. Nietzsches Philosophie der ewigen Wiederkehr des Gleichen. Hamburgo: Felix Meiner Verlag, 3a ed., 1978. p. 42). Cf. numa direção análoga FOUCAULT, Michel. Les mots et les choses. Paris: Gallimard, 1966, p. 317.

31 Temas recorrentes em Assim falava Zaratustra, eles encontram-se expressos de forma exemplar na seção "Dos mil e Um alvos".

32 Cf. respectivamente Ecce Homo, "Por que sou um destino", § 7, KSA 6.372; Fragmento Póstumo 14 [103] da primavera de 1888, KSA 13.281; Crepúsculo dos Ídolos, "Os quatro grandes erros", $\S 8$, KSA 6.96.

33 Em Assim falava Zaratustra, "Prólogo", 4" seção (RRTF), KSA 4.17, lemos: "Amo Aqueles que não procuram atrás das estrelas uma razão para sucumbir e serem sacrificados", afirma Zaratustra; "mas que se sacrificam à Terra, para que a Terra um dia se torne do além-do-homem".

34 Aplicado ao sol e também a Zaratustra, o termo untergehen inscreve-se em diferentes registros: alude ao ocaso do astro e à descida da personagem ao vale; comporta ainda a ideia de declinar, ir abaixo, sucumbir.

35 Cf. BÍBLIA SAGRADA. Trad. João Ferreira de Almeida. Rio de Janeiro: Sociedade Bíblica do Brasil, 1968, Lucas, 3, 23.

36 Cf. PLATÃO. République. Trad. Émile Chambry. Paris: Belles Lettres, 1933, livro VII.

37 Cf. carta a Georg Brandes de 23 de maio de 1888, KSB 8.318.

38 Sigo a tradução de Rubens Rodrigues Torres Filho, que esclarece: "Wirklichkeit - termo usual alemão para designar o 'real', a 'realidade'; do verbo wirken (fazer efeito), que em linguagem filosófica designa, especificamente, a atuação da causa (eficiente) na produção do efeito (Wirkung). Nietzsche faz questão dessa derivação, já desde o texto de $1873 \mathrm{em}$ que cita, a propósito de Heráclito, esta passagem de Schopenhauer: 'Causa e efeito são, portanto, toda a essência da matéria. Seu ser é seu efetuar-se. É com o maior acerto, portanto, que em alemão o conjunto de tudo o que é material é denominado efetividade, palavra que o designa muito melhor do que realidade' (Cf. A filosofia na época trágica dos gregos § 5)" (Nietzsche - Obras incompletas. São Paulo: Abril Cultural, 2a ed., 1978 (Coleção "Os Pensadores"), p. 197, nota 2).

39 No Ecce Homo, Nietzsche esclarece: “A palavra 'além-do-homem', como designação do tipo mais altamente bem logrado, em oposição ao homem 'moderno', ao homem 'bom', aos cristãos e outros niilistas - uma palavra que, na boca de um Zaratustra, do aniquilador da moral, se torna uma palavra que dá muito o que pensar -, foi, quase por toda parte, com total inocência, entendida no sentido daqueles valores cujo oposto foi apresentado na figura de Zaratustra: quer dizer, como tipo 'idealista' de uma espécie superior de homem, meio 'santo', meio 'gênio'..." (Ecce Homo, "Por que escrevo livros tão bons", § 1 
(RRTF), KSA 6.300).

40 É em Assim falava Zaratustra, "Prólogo", $3^{\mathrm{a}}$ seção, que Nietzsche introduz esta perspectiva avaliadora.

41 Cf. nessa direção LÖWITH, Karl. "Nietzsche et sa tentative de récupération du monde". In: Nietzsche, Cahiers de Royaumont. Paris: Minuit, 1967, p. 45.

42 Cf. Assim falava Zaratustra, Prólogo, $9^{\text {a }}$ seção, KSA 4.26: "Companheiros de viagem busca o criador e não cadáveres, nem tampouco rebanhos e crentes. Participantes na criação busca o criador, que escrevam novos valores em novas tábuas. Companheiros de viagem busca o criador e participantes na colheita: porque nele tudo está maduro para a colheita. Mas faltam-lhe as cem foices: por isso arranca as espigas e está irritado. Companheiros de viagem busca o criador, e tais que saibam afiar suas foices. Aniquiladores serão chamados e desprezadores do bem e do mal. Mas são eles os colhedores e festejadores".

43 Cf. Para além de Bem e Mal § 211 (RRTF), KSA 5.145: "Os filósofos propriamente ditos, porém, são comandantes e legisladores: eles dizem 'Assim deve ser!'; são eles que determinam o Para-onde? e o Para-quê? do homem e para isso têm a seu dispor o trabalho prévio de todos os trabalhadores filosóficos, de todos os dominadores do passado estendem sua mão criadora em direção ao futuro, e tudo o que é e foi se torna para eles meio, instrumento, martelo. Seu 'conhecer' é criar, seu criar é uma legislação, sua vontade de verdade é - vontade de potência. - Há hoje tais filósofos? Houve já tais filósofos? Não é preciso haver tais filósofos?"

44 Cf. num sentido análogo Assim falava Zaratustra I "Das moscas do mercado", KSA 4.65: "No mundo as melhores coisas não valem nada, sem que alguém as apresente".

45 Vale lembrar o comentário léxico de Rubens Rodrigues Torres Filho: "'Mensch, das ist: der Schätzende: na origem da palavra Mensch, mannisco, substantivação do velho-altoalemão mennisc (humano), encontra-se o radical indogermânico men (pensar), o mesmo que em latim deu mens (mente) e mensurare (medir). Talvez Nietzsche se refira a este último sentido, tanto mais que 'pensar' guarda lembrança de: tomar o peso, ponderar. Schätzen por: estimar, avaliar, apreciar, dai Schätzende, o que estima, o taxador" (Op. Cit. p. 233, nota 4).

46 Assim falava Zaratustra I "Dos mil e Um alvos" (RRTF), KSA 4.75.

47 Cf. A Gaia Ciência § 346 (RRTF), KSA 3.581: "Não caímos, justamente com isso, na suspeita de uma oposição, de uma oposição entre o mundo em que até agora nos sentíamos em casa com nossas venerações - em virtude das quais, talvez, tolerávamos viver - e um outro mundo, que somos nós próprios: uma inexorável, radical, profundíssima suspeita sobre nós mesmos, que se apodera de nós, europeus, cada vez mais, cada vez pior, e facilmente poderia colocar as gerações vindouras diante deste terrível ou-ou: 'ou abolir vossas venerações, ou - vós mesmos!' Este último seria o niilismo; mas o primeiro não seria também... o niilismo?"

48 No artigo "A palavra de Nietzsche: 'Deus está morto", Heidegger analisa a concepção nietzschiana de niilismo em seus diversos aspectos. Entendendo-o como um processo histórico e pensando-o como a lógica interna da História Ocidental, Nietzsche concebe o niilismo como a "desvalorização dos valores até agora supremos". É incompleto, quando, a despeito de suprimir Deus, mantém o mundo supra-sensível; os antigos valores podem ser substituídos por outros, mas estes continuam a ser colocados no mesmo lugar que ocupavam os anteriores. É acabado, quando chega a eliminar o mundo supra-sensível, o lugar mesmo dos valores, pondo-os de outra maneira e invertendo o seu valor. No entender de Heidegger, ao afirmar que "Deus está morto", Nietzsche dá nome ao destino de vinte séculos da História Ocidental. Apreendendo-a como o advir e o desdobrar-se do niilismo, acaba por interpretá-la metafisicamente. Ao anunciar a morte de Deus, quer dizer que o mundo supra-sensível não tem poder eficiente e considera assim a sua própria filosofia um movimento antimetafísico, antiplatônico. Apesar disso - é o que Heidegger quer mostrar -, permanece ligado à essência daquilo a que se opõe. Embora dele nos distanciemos, quando procura reinscrever o pensamento nietzschiano na história milenar da metafísica, com ele concordamos quanto à maneira de caracterizar o niilismo incompleto e o niilismo acabado. (Cf. "Nietzsche's Wort 'Gott ist tot". In: Holzwege. 
Frankfunt am Main: Vittorio Klostermann, 2a ed., 1952).

49 Assim falava Zaratustra I "Dos mil e Um alvos" (RRTF), KSA 4.75. Cf. também Assim falava Zaratustra, "Prólogo", 9 9 seção (RRTF), KSA 4.26: "Vede os bons e justos! Quem eles odeiam mais? Aquele que quebra suas tábuas de valores, o quebrador, o infrator: - mas este é o criador. Vede os crentes de toda crença! Quem eles odeiam mais? Aquele que quebra suas tábuas de valores, o quebrador, o infrator: - mas este é o criador". 